\title{
Understanding social transition through the lens of curriculum policy: Namibia/South Africa
}

JONATHAN D. JANSEN

Whatever the political origins of the reference of Namibia as 'South Africa's fifth province', it is not an exaggeration. Few countries in post-colonial Africa are likely to have reflected more in style and substance the indelible image of the colonial power as has Namibia. Indeed, for many white Namibians their political identity remains indissolubly linked to Pretoria; and the cultural identity of many black Namibians has been significantly impacted on by the institutions of South African colonialism. Nowhere was this linkage more tangibly demonstrated than in the school curriculum. And in few places was this identity more contested than in the struggle over the school curriculum in the first three years of independence. This paper analyses the politics of transition in Namibia through the medium of four case studies of curriculum reform which illustrate the tensions between change and continuity since 1990 when 'Africa's last colony' won political independence from South Africa. ${ }^{1}$ Alternatively, the paper could be read as an assessment of South Africa's colonial impact on the process of transition in Namibia in the context of school curriculum reform. The Namibian case study is informed by two established theoretical traditions: the politics of transition and research on the politics of curriculum.

\section{Background}

Namibia gained independence on 21 March 1990 from, first, German colonialism (19941915) and then South African occupation (1915-90). ${ }^{2}$ The struggle for liberation is well documented and will not be rehearsed for the purposes of this paper; suffice is to note that the Namibian people used various instruments for opposing colonial domination including civil protests, legal and political injunctions through the United Nations and an armed insurrection led by the South West African People's Organisation or SWAPO (Namibia Support Committee 1988). Despite a long history of resistance, Namibia's mode of transition conditioned its capacity to effect radical change in the educational system inherited at independence. It is important, therefore, to begin with an analysis of Namibia's social transition in order to comprehend its effects on curriculum policy since independence. 


\section{On the politics of transition}

Explaining social transition in late-colonial states emerging in the post-Cold War environment requires new theoretical insights which move beyond the regnant paradigms in leftist writings on the Third World which assume a reform trajectory directed or informed by socialist ideology (Fagan 1986, Carnoy and Samoff 1990, Saul 1990). ${ }^{3}$ Such theoretical explorations must now take account of the changes in global superpower politics at the end of the 1980 s and their impact on late-colonial states such as Namibia ${ }^{4}$.

The end of colonialism in Namibia coincided with the fall of Eastern European socialist regimes and the changes in regional political strategies of the Soviet Union which accompanied Mikhail Gorbachev's 'novoe politicheskoe myshlenie' or new political thinking in foreign affairs (Duncan and Ekedahl 1990, du Toit 1990, McFaul 1990, Meyns 1991). It also came at a time when southern African states which had engaged in radical political experimentation since the end of English and Portuguese colonialism were reversing course from the radical polities adopted at independence (Jansen 1991b, Daun 1992).

Accordingly, the changes in regional and global politics conditioned the Namibian transition in the following ways. First, it was no longer tenable, or even advisable, for the SWAPO-led government to define its political transition in terms of a socialist agenda. Regional states (such as Zimbabwe and Mozambique) were moving in exactly the opposite direction by the end of the decade of the 1980s, in part due to the economic declines suffered in these countries, in part due to eroding support from the Eastern bloc in the throes of political and social upheaval, and in part because of the increasing pressure of these states to conform to the dictates of the International Monetary Fund which changed not only the nature of state-dominated economies (Mozambique; Daun 1992) but also the political claims for pursuing socialism (Zimbabwe; Jansen 1993). Late-colonialism in Namibia essentially meant that regional support for a radical social and political direction was severely limited.

Second, the small electoral victory, albeit a majority (57.3\%; table 1), essentially committed the SWAPO-led government to gradualism in its political agenda. Small but powerful opponents were represented in the Namibian parliament to secure the interests of the white minority and other conservative political parties. According to Sparks and 
Green (1992: 156, 157). 'The multiparty election in November 1989 resulted in a system in which one party does carry a majority, but the majority is sufficiently weak to necessitate coalition politics', and as a consequence, they predicted accurately that 'The new government will have little leverage in radically changing its [economic] policies in the short term'.

Table 1. 1989 election results.

\begin{tabular}{|c|c|c|c|}
\hline Party & $\begin{array}{c}\text { Popular } \\
\text { vote }\end{array}$ & $\%$ & $\begin{array}{c}\text { No. } \\
\text { of } \\
\text { seats }\end{array}$ \\
\hline Aksie Christelik Nasionaal & 23728 & 3.5 & 3 \\
\hline Christian Democratic Action for Social Justice & 2494 & 0.0 & 0 \\
\hline Democratic Turnhalle Alliance & 191532 & 28.6 & 21 \\
\hline Federal Convention of Namibia & 10452 & 1.6 & 1 \\
\hline NNDP - $\quad$ Namibia National Democratic Party & 984 & 0.1 & 0 \\
\hline Namibia National Front & 5344 & 0.8 & 1 \\
\hline NPF - $\quad$ National Patriotic Front & 10693 & 1.6 & 1 \\
\hline SWAPO/D - South West African People's Party Democrats & 3161 & 0.5 & 0 \\
\hline SWAPO - $\quad$ South West African People's Party & 384567 & 57.3 & 41 \\
\hline United Democratic Party & 37874 & 5.6 & 4 \\
\hline Totals & 670830 & $99.6^{*}$ & 72 \\
\hline
\end{tabular}

Third, the brokered negotiations committed all key parties to the politics of compromise rather than to radicalism on the part of the SWPO government. ${ }^{5}$ This was particularly important for South Africa since it had a vested interest in the remaining white Namibians whose identity was closely linked to that of the regional colonial power.

Fourth, the SWAPO government itself initiated a 'policy of reconciliation' (as did the ZANU government of Robert Mugabe after Zimbabwean independence in 1980) which set the conditions of transition in gradualist and reconciliatory terms. This policy was first enunciated in President Nujoma's (quoted in Pitswane 1992: 113) inaugural address: 
Taking the destiny of this country in our own hands means, among other things, making a great effort to forge national identity and unity. Our collective security and prosperity depend on our unity of purpose and action. Unity is a precondition for peace and development.

Since that time the policy has been announced widely, by senior officials, such as the address of Prime Minister Hage Geingob on the occasion of the Namibia Donors Conference in New York where he claimed that 'Now that Namibia has won its national sovereignty, the struggle for national reconciliation....has begun' (Namibia Donors Conference 1990:20).

And fifth, the much-needed support required for meeting rising expectations among black Namibians from the international donor community (particularly the USA and the UK) was conditional upon the pursuit of a non-radical strategy for social transformation (Wood 1993: 68-69). It is striking that at two critical conferences, the Foreign Investors Conference (Windhoek, 3-6 February 1991) and the earlier Donor Pledging Conference (New York, 21-22 June 1990), Namibian officials went to great lengths to signal to donors their willingness to provide 'the guarantees that international investors normally expect' (Namibia Donors Conference 1990:4; quotation from speech by the Director-General of the National Planning Commission). Overarching this 'softening' of economic strategy was an earlier study by the World Bank (1992: xvi, xvii, xix, xxix) which made the startling claim that 'The economy's poor performance [under apartheid] was not the result of erroneous policies', emphasized that 'Namibia has no history of interfering with market forces in resource allocation', and recommended that 'The Namibian authorities do not need to make radical changes to current policies, or adopt drastically new policies to stimulate investment'. Throughout, the spectre of failed radicalism was held up for scrutiny:

Namibia begins its independent life highly indebted... . The world is replete with countries that have borrowed only to invest poorly or to sustain short-lived bonanzas. They are now undergoing painful adjustments. Namibia does not need to repeat these mistakes.

In addition, Namibia promulgated the Foreign Investment Act (December 1991) which 'institutes a liberal foreign investment regime with guarantees against nationalism and permitting the repatriation of profits' (Simon 1991:15). Against this background, several long-time observers of SWAPO policy have echoed du Pisani's (1991:15) observation that 'its socialist policy programme of 1976 now seems a distant memory'. 
In short, the conditions for social transformation in Namibia were much more limited than was the case with other regional states when these first gained independence in the previous two decades. It could be expected, therefore, that for the emerging state the shaping of curriculum policy under the limiting conditions of the 1990's would inevitably be a political event.

\section{On the politics of curriculum}

This paper builds on the well-established critical literature on the school curriculum which has emerged during the last two decades. ${ }^{6}$ This literature holds that the school curriculum is not simply a technical document outlining intended learning outcomes or specifying content to be covered or teaching strategies and assessment procedures to be used. It is fundamentally, a political document which reflects the struggles of opposing groups to have their interests, values, histories and politics dominate the school curriculum. This is particularly striking in societies undergoing political change, as is the case in Namibia.

In Official Knowledge, Michael Apple (1993: 10) observes that 'the politics of official knowledge are the politics of compromises and accords'. In the Namibian transition, premised as it is on the politics of 'compromises and accords', the school curriculum (the embodiment of 'official knowledge') is an invaluable lens through which to understand the politics of transition, i.e. the conflicts and compromises struck within and outside the state, and their effects on the pace, direction and content of transition in Africa's most recent democracy. But states and their opponents seldom take to the streets to engage openly in trench warfare on differences in educational policy; that would make the task of the analyst much simpler. Rather, the conflicts are often concealed and denied, confounding the analytical task of attempting to unravel such struggles by examining events or documents which provide insight into those conflicts. The school curriculum, the most tangible expression of national values and interests, is an ideal document for studying the politics of transition - as should be evident in this case study of Namibia.

\section{On curriculum policy in Namibia}

Namibian curriculum policy immediately prior to independence mirrored the Bantu Education curriculum in South Africa which was premised on notions of white supremacy, 
racial and ethnic separation, centralized control of curriculum decision making, and the highly unequal provision of basic curriculum resources (i.e. textbooks, writing materials, specialist equipment, etc.) along racial lines (Ellis 1984). Where the Eiselen Commission laid the basis for Bantu Education in South Africa in the late 1940s, the Van Zyl Commission (1958) and later the Odendaal Commission (1962) simply applied the administrative and ideological extensions of the Eiselen report to specific conditions in Namibia (Liu 1980, Ellis 1984, Salia-Bao 1991). ${ }^{7}$

Given this curriculum linkage to apartheid South Africa, it was immediately clear after independence that the emerging state would make the school curriculum a principal focus of the transformation/reconstruction effort in Namibia. ${ }^{8}$ It was equally clear that this was to be an area of contestation which would directly and intensely engage the state and rival forces within it long after the new flag was hoisted over Windhoek in March 1990. We examine briefly four short case studies of curriculum reform in Namibia with the goal of illuminating the politics of transition in a late-colonial state.

\section{Case study 1: On curriculum decision-making}

Curriculum policy in Namibia emanates from different sources developed before and since independence. At least three key documents emerged in 1990 to lay the foundation for educational policy broadly and curriculum policy in particular: Draft Proposal for Education Reform and Renewal (January 1990), Education in Transition: Nurturing our Future (July 1990) and Change with Continuity: Education Reform Directive: 1990 (November 1990). Buttressed by a stream of consultancy reports commissioned during the first two years of independence, ${ }^{9}$ the accumulated educational thinking and experience developed during the years in exile, and particularly through the United Nations Institute for Namibia in Lusaka, and sector studies by international donors, ${ }^{10}$ the educational leadership in Namibia started to craft a national curriculum policy for Namibia. Other documents then emerged to elaborate earlier positions, such as Education and Culture in Namibia: The Way forward to 1996 (dated 28 November 1991) and Pedagogy in Transition: The Imperatives of Educational Development in the Republic of Namibia (dated May 1991). Perhaps the most important legal document for educational policy to emerge during early independence is the Namibian Constitution itself which in articles 3 and 20 respectively outlines the role of languages in schools and the rights of all children to education on a non-discriminatory basis. All these various sources culminated in the Development Brief 
for Education, Culture and Training in Namibia which was adopted by the Namibian Parliament in 1993 as 'constituting a broad policy vision to guide all actors in [this] vital field' (Ministry of Education and Culture 1992b:2).

While there are rich and multiple documentary sources to inform curriculum policy in Namibia, the process of curriculum decision making within the educational bureaucracy is more complex than simply a 'reading-off' of information from research and consultation documents. Curriculum decision making within the Ministry of Education and Culture is located within different bureaucratic structures. Implementing curriculum policy in the form of curriculum materials (i.e. textbooks, syllabuses and other material resources) is the responsibility of the Division of Curriculum Development and Research within the National Institute for Education Development (NIED), generally regarded as the R\&D unit of the Ministry. Other bureaucratic structures responsible for teacher education, language policy and the development of subject-specific curriculum materials co-exist within the Ministry and have an equally important role in curriculum development. In addition, the Minister himself is involved with small ad hoc working groups or consultants in designing and implementing educational policy outside the direct and general influence of NIED. There are also informal networks of conservative bureaucrats from the previous regime (often Afrikaans-speaking civil servants) who make critical decisions within the Ministry and who have influential connections to the white community and narrow technical expertise. Furthermore, the infusion of external expertise, mainly through a Ministry contract with Florida State University (funded by USAID), has generated another level of curriculum decision making; while aligned with the Minister's policy and political goals, this expertise adds another layer of educational and curricular knowledge and decision making into the bureaucracy. There are also individuals from Scandinavian countries and the UK, all adding external knowledge and expertise to the curriculum bureaucracy. In short, the de facto curriculum policy which emerges from this complex bureaucratic system is not simply an implementation of curriculum policy outlined in state documents, for reasons which are not discussed.

The complex curriculum bureaucracy ${ }^{11}$ is no accident, it is a function of the traditional environment inherited at independence. First, the retention of Afrikaner civil servants, often in key bureaucratic positions, is a deliberate and conscious compromise which the Namibian Government committed to at independence. Article 141 of the Namibian 
constitution deals with 'Existing Appointments' (Government Gazette 21 March 1990, No. 2:70) and holds that:

Subject to the provisions of this Constitution, any person holding office under any law in force on the date of Independence shall continue to hold such office unless and until he or she resigns or is retired, transferred or removed from office in accordance with law.

Significantly, the heads of both Formal Education and of the Division of Curriculum Development and Research within NIED are senior Afrikaner bureaucrats. That such critical positions, which could clearly undermine the transformation of the school curriculum, would be occupied by conservatives from the previous apartheid regime is a very significant comment on the degrees of freedom available to the new government to implement radical social (or educational) change. Furthermore, the limits placed on hiring new senior personnel to replace previous regime staff by the Public Services Commission (itself a legacy of the apartheid bureaucracy) put an effective brake on the reform process.

Second, in addition to the retention of Afrikaner civil servants there were simply not enough Namibians with expertise in the technical areas required for curriculum development. In fact, it is a sad commentary on the legacy of apartheid that all senior positions within the bureaucracy (with few exceptions) are occupied by hite Namibians and foreigners and that the black Namibians are disproportionately located within the African Languages division of the Ministry.

Third, the Minister, Nahas Angula, plays an unusually activist role in the operations of the different divisions of the Ministry. He chairs certain crucial portfolios and is directly involved in policy deliberations on language and teacher education. He comments extensively on emerging policy decisions and participates directly in the many routine bureaucratic decisions made within his Ministry.

Fourth, another strategy utilized by the Minister is the setting-up of parallel structures of decision making within the Ministry. This strategy frustrates the conservatives who may engage in decision making along the lines specified within the official organization chart only to find that power and authority to carry forward decisions have been located in an interim committee reporting directly to the Minister. This was particularly evident in the events leading to the decision on English as the language of instruction for Namibia's schools. 
Fifth, to counteract expertise and influence within the Ministry, a strong contingent of foreign expertise was brought into Namibia, both as staff within the Ministry of Education and Culture and as short-term consultants to develop critical documents to inform national policy and planning. For example, during 1002 five educational planners were appointed, eight vacant posts were advertised and 11 foreign advisors served in the Directorate of Curriculum Research and Development alone (Ministry of Education and Culture 1992a: 71)! These sources of expertise have had the important effect of counter posting educational strategies, on behalf of the Ministry, which effectively undermined conservative expertise from the previous regime. On the other hand, the influx of foreign expertise invariably limited the scope for development of black Namibians and, however well intentioned, simply inserted research and information based on assumptions and values generated outside Africa.

This analysis of staffing strategies within the curriculum bureaucracy outlines the inherent conflicts associated with a policy which ensured continuity with the educational system inherited at independence even as the new government sought opportunities to change the curriculum within this limiting environment. The external manifestation of this decisionmaking complex was in the form of specific policies pursued for the school curriculum; these policies are now assessed.

\section{Case study 2: Language policy}

The most visible legacy of apartheid in the institutions of Namibia is the Afrikaans language. The new government placed considerable policy and political resources in addressing the language question shortly after independence. The language position of the new state was immediately inserted in the Constitution, but even here the ambiguities of transition are reflected.

\section{Article 3 Language}

[1] The official language of Namibia shall be English.

[2] Nothing contained in this Constitution shall prohibit the use of any other language as a medium of instruction in private schools or in schools financed or subsidized by the State... 
[3] Nothing contained in Sub-Article (1) hereof shall preclude legislation by Parliament which permits the use of a language other than English for legislative, administrative and judicial purposes in regions or areas where such other language or languages are spoken by a substantial component of the population

Namibian language policy was developed as early as 1983 at a SWAPO Conference in Lusaka on a policy framework for independent Namibia. emerging official positions on language were contained in the early educational policy documents which also served as the basis for discussion and inputs from a variety of stakeholders. The final and comprehensive position of the government is contained in the document Language Policy for Schools 1992-1996: Explanatory and Information Statement by the Ministry of Education and Culture. (Windhoek, 28 November 1991). Summarized, language policy for schools is based on the following guidelines:

(a) In Grades 1-3 learners will be taught in the mother tongue as 'the best foundation for later learning in another language medium' (Curriculum Guide for Formal Basic Education, October 1992, Version 7: 23).

(b) All learners should acquire competence in English during the 7-year primary cycle. In grades 4-7 English will be phased in as the main medium of instruction for promotional subjects other than languages.

(c) In the secondary school, English will be phased in at Grade 8 from January 1991 so that by 1995 all secondary grades will be taught through the medium of English.

There were several reasons for this radical but risky shift in curriculum policy during early independence. Such reasons include the need to enhance socio-economic possibilities with the broader international community; the need to institutionalize a language which could unify Namibians across the ethnic and racial divides enforced by the extension of apartheid in the form of 11 education departments; the need to adopt a language policy which would facilitate mobility among Namibians within the country and across international borders. However, these reasons are not sufficient to explain such a dramatic move with its important political consequences, if only because the numerically small but politically significant number of white4s remaining after independence would clearly mark this shift as a direct challenge to their privilege and power, which remained relatively intact despite the change of government in March 1990. 
A more potent explanation lies in 'the felt political need to make a visible break with Afrikaner colonialism and its manifestations, such as the pervasive use of the Afrikaans language' (Policy Dialogue Reports, Language Policy 1993: 2). That is, the Minister defined his political strategy directly in relation to the apartheid state's most visible postcolonial cultural presence in Namibia. The need to break the colonial ties with South Africa overrode any other considerations in the choice of English as the medium of instruction for Namibian schools.

There remain many reasons why in simply practical terms this shift was extremely risky. First, Afrikaans, while being an imposition of apartheid, was nevertheless spoken widely as the common language in most education regions of Namibia. Second, by the end of 1992 most of the available textbooks, syllabuses and 'schemes of work' available in the schools were in Afrikaans. And thirds, competency in English was likely to be a significant barrier to effective communication in schools not only for learners but for teachers and principals as well, e.g. in three of the northern rural areas I visited many school principals preferred to conduct interviews in Afrikaans rather than in English even though their first language was an African language. All of this was clear to the Ministry both in the form of instant feedback from the regional offices and from its own research reports (Directorate of Language Research and Development 1992: 6-7), extracts from which appear below:

\section{Main Problems in Teaching English}

\section{Teacher's Ability}

No training in English language teaching.

Has to translate Khoekhoegawab to Afrikaans to English, and teacher's knowledge of Khoekhoegowab is limited.

Own language competency is limited.

No opportunity to practise own English, so poor in vocabulary.

\section{Language environment}

Otjiherero medium in Grades 1 to 3, Afrikaans in Grades 4 to 7, so learners cannot understand English.

English is not spoken outside the classroom and teaching is done through translation. 
Lack of English background of learners and assistance from parents.

This analysis is not meant to suggest that choosing of English was a 'mistake' in policy choice; those choices remain the preserve of the Namibian people. However, the point of the analysis is simply to show that, against overwhelming political odds, one instance of a radical shift from the previous regime came in the language policy chosen for schools as an imperative, and that this choice had a strong political rationale which overrode other considerations.

\section{Case study 3: Junior Secondary Curriculum reform}

Few curriculum reforms raised as much public outcry as the decision to reform, with considerable speed, the Junior Secondary Curriculum (JSC) starting in January 1991. Several reasons were offered for selecting the Junior Secondary phase for initial reforms such as the relatively small number of schools and learners involved, the relatively low costs of introducing reform at this level, and the fact that children at this level already had sufficient background knowledge to adapt to the proposed changes without much trauma. The principal changes in the JSC were the immediate shift to English as medium of instruction, the introduction of mathematics and science as compulsory school subjects, and the choice of 'vocationally orientated' subjects which aim to teach technological and industrial skills. What drew public criticism was not so much the content of the reform (even though there was commentary on the language issue in particular) but the extraordinary haste in pushing through this curriculum. As one commentator (HarlechJones 1992: 3) observed:

\footnotetext{
Within six weeks, the curriculum was finalized. Subject committees drafts syllabi, which were sent out to all the regions, the colleges, etc. Schools received the New National Curriculum for Junior Secondary Education together with all syllabi in December 1990. Teachers began to implement the curriculum in Grade 8 January 1991. During the first half of 1991, about 3,500 teachers attended courses designed to assist them in implementing the new curriculum and syllabi.
}

Subsequently, many voices from the teaching community, regional education offices (particularly those outside the capital, Windhoek) and parents challenged the government on the haste followed in pushing the JSC reform; they cautioned that amore thorough consultative process be followed, allowing for more time during which teachers could familiarize themselves with the details of the content and intentions of the intended reform. 
Much of the analysis of the JSC reform movement ends here. It correctly identifies the dilemmas of haste in decision making and implementation of the curriculum; it legitimately complains that 'the lack of participation of teachers outside of Windhoek had been a strategic error' (Harlech-Jones 1992: 3); and it defensibly argues for a gradual, phased-in approach to curriculum reform. What such analysis does not offer, however, is an explanation as to why the newly elected Namibian government would risk such a pace in its curriculum reform initiative given its unquestionable commitment to a democratic and consultative process, particularly in relation to its constituency.

After reviewing the documentary evidence and following wide-ranging interviews within and outside the state bureaucracy, it is clear that there was a very important political imperative to demonstrate change from apartheid status quo as soon as possible after independence. As mentioned earlier, the Namibian mode of transition was severely limited not only by the general post-Cold War environment which dictated gradualism in late-colonial transitions, and the conservatism inherent in the educational system, but also by the compromises reached during negotiations and protected within the constitution. There were few opportunities for the recent liberation movement - now recognized government - to demonstrate to its constituency that its coming to power signalled a shift from the apartheid legacy. Something had to be done quickly and concretely to signal change, and the JSC provided one such opportunity. The following observations by a group of visiting policy analysts from South Africa (Policy Dialogue Reports: Language Policy 1993: 3) were accurate:

It should [also] be pointed out that while the Namibian education authorities reportedly placed a lot of emphasis on consensus-building...they were faced with an urgent need to begin enacting visible changes in the socio-cultural functioning of the system, even as they were engaged in a process of re-framing the system. Thus, as a result of managing the tension between the urgency of visibly delivering on pre-liberation popular expectations on the one hand, and thorough democratic participation on the other, some elements of the new policy got implemented even before the consultation on the policy was wound up.

The JSC reform initiative was therefore an opportunity to forge change within one component of the school system in the context of a largely unchanged educational system conditioned by the Namibian mode of transition at the same time as there was increasing pressure to demonstrate change to the SWAPO constituency after independence. 


\section{Case study 4: Reforming the examination system}

Several consultancy reports generated in the first months of independence agreed on the severe restrictions in the inherited examination system. ${ }^{12}$ One report (Bethell 1990: 8; quoted in Toward Education for All: A Development Brief for Education, Culture and Training) observed that:

This emphasis on failure is endemic throughout the education system with students expecting to fail, teachers expecting them to fail, and Examiners setting papers to ensure that large numbers do fail. If this situation is to be reversed and the emphasis placed on positive achievement then a great effort will need to be made to re-educate all concerned.

Another review (USAID 1990: S IX-11) similarly observed that: 'The rigid examination system, administered under tight central control, has resulted in a system where the vast majority of pupils fail at all levels in the name of "standards"'.

The examination system, as with other components of the school curriculum, reflected the image and substance of apartheid education policy. Examinations were standardized despite the fact that classroom resources were highly unequal throughout the system; the examinations merely served to reinforce the content specified in the syllabus, which was highly biased in race and gender terms. As the Director of Examinations observed, 'clearly a major objective [of the examination reform] was to begin the lengthy process of mental decolonization away from the images of an inferior and separate people which permeated the old curriculum and pedagogy' (quoted in Policy Dialogue Reports: Examinations 1993: $3)$.

Furthermore, the Namibian examination system at the high school level was tied directly to the matriculation examination of the Cape Education Department (CED) in South Africa. The examinations of the CED are based on core syllabi which are set by the white education authorities in South Africa.

The examination system is another example of the tension for change with the pressure for continuity which faced the SWAPO-led government in general and the Ministry of Education and Culture in particular. Despite the colonial roots of the senior examination system, this connection to the white CED continued throughout the first three years of independence. It was a specific policy choice on the part of the Ministry that any reform in examinations policy would be gradual, not fundamental; incremental not system-wide. In 
this way the neo-colonial linkage to South Africa was maintained during the crucial first three years of independence.

However, the Minister announced almost immediately after independence that the examination system would have to be reviewed. Negotiations were initiated with the University of Cambridge Local Examinations Syndicate to begin phasing in the International General Certificate for Secondary Education and the Higher International General Certificate for Secondary Education by 1994, and some white private schools began experimenting with these qualifications during 1992-3. Several issues in this policy shift from the CED to the Cambridge Syndicate provide useful insights into the politics of transition in Namibia.

Again, the strong commitment of the Minister to delinking from the South African educational system (as with the Afrikaans language) overrode other considerations in examinations policy. Given its late-colonial status, the Namibians were no doubt aware of the damaging effects of the Cambridge examinations in southern African countries such as Zimbabwe where these examinations were extremely costly and a drain on foreign exchange resources, very difficult for African students disadvantaged by years of inferior education in the grades leading up to matriculation, and heavily biased in cultural and social content to the European context.

Indeed, in the view of some Namibian officials, linking to Cambridge was simply exchanging South African colonialism for British imperialism. However, in political terms the shift provided the Minister with some vindication for ending South African control while at the same time appeasing conservative white Namibians that 'standards' would not be dropped by linking to the prestigious Cambridge examinations system. In any event, for Namibia to design its own examinations for the matriculation year - which bridges students into post-secondary education - would, quite apart from concerns about technical capacity, have brought tremendous pressure in terms of political legitimacy.

\section{Social transition and curriculum policy in late-colonial states: some preliminary conclusions}

In their seminal contribution on Transitions from Authoritarian Rule, O'Donnell and Schmitter (1990) describe one mode of transition as 'pact-formation' in which opposing 
political groups enter into negotiations in recognition of the fact that neither one group is able to defeat the other in the struggle for political power. These groups then enter a series of pacts which are designed to protect their respective self-interests while simultaneously engaging in compromises and accords which provide less than the maximalist demands originally articulated by each group in the struggle. In the words of O’Donnell and Schmitter (1990: 38):

The general scenario for negotiating a pact is fairly clear: it is a situation in which conflicting groups are interdependent, in that they can neither do without each other nor unilaterally impose their preferred solution on each other if they are to satisfy their respective divergent interests.

In Namibia, as in South Africa, the changes in regional politics which in turn were nested within global cold War politics were informed in part by the observation that regional wars (as in Mozambique and Angola) could drag on indefinitely with devastating effects on the countries concerned without any long-term settlement which could restore political order and economic stability. The shift in Soviet/Cuban (and subsequently US) perspectives on regional conflicts changed the ideological and material resource base for anti-colonial struggles in southern Africa at the same time as it enabled the pro-colonial forces to change the rationale in pursuit of an ultimate victory against 'communist' forces. In particular, South Africa's decision to negotiate Cuban withdrawal from southern Angola in exchange for granting independence in Namibia was facilitated by changing superpower politics at the close of the previous decade. In addition, the fact the neither the SWAPO forces nor the South African Defence Force could in themselves decisively swing the war of more than two decades in their favour made possible a series of negotiations with SWAPO in run-up to and following on independence in March 1990. The South African and the emergent Namibian governments negotiated crucial agreements on the transition (including the controversial ownership of Walvis Bay after independence but which was recently "turned over" to Namibia by the South African Government). Governed by the political and development aid oversight of the USA and the UN, these negotiations, in conjunction with the shifts towards capitalism in neighbouring countries, placed the small Namibian state in a position where its 'pact' required gradualism in social transition which resulted in a moderate educational and curriculum reform agenda. Perhaps the title of one of the founding educational policy documents of transition best reflect this moment:

\section{Change with Continuity.}


The purpose of this paper was to examine the consequences of pact formation in Namibia through examination of the detail of curriculum reform processes and decision making (the four mini-case studies) and in the context of national, regional and global conditions facing late-colonial states in the post-Cold War era. Utilizing the theoretical contribution of O'Donnell and Schmitter (1990), the following findings from the Namibian case provide the basis for elaboration and application of their work in the context of educational politics in the Third World.

- The significance of curriculum as a focus for transitional politics in late-colonial states. Few studies in the Third World have examined the relationship between curriculum reform and social transition in post-colonial states. This study is both a contribution to and a call for further research in this important area of African studies and educational scholarship.

- The critical importance of regional and global factors in conditioning the ways in which transition unfolds in particular settings, even while these may be governed by broader political and theoretical frameworks which apply across nationstates. Few existing studies within the radical tradition have delivered novel theoretical insights into social transitions in developing countries since 1990. Clearly dependency theory, socialist revolution theories, or even theories of post-colonial nationalism, are insufficient to account for the social change trajectories followed in late-colonial states.

- The political dilemmas of change and continuity as expressed in the actual decisions made by emerging states, expressing a constant dialectic which engages the late-colonial state in walking a tightrope between the conflicting demands of legitimacy in relation to its black constituency and control and dependency in relation to regional and global powers. This study therefore moved beyond large-scale accounts of a macro-political nature by examining the processes by which states make decisions on a day-to-day basis and linking those decision-making processes to changes in national, regional and global political developments. More investigations are needed which link micropolitical behaviours with macro-political conditions if we are to deepen our understanding of education and social transition in late-colonial states. 
The subtitle of O'Donnell and Schmitter's (1990) contribution is tactfully rendered as Tentative Conclusions about Uncertain Democracies. Indeed, the course of and commitment to the Namibian pact with South Africa and the international community on the one hand, and the project of post-apartheid democratization on the other, will continue to represent a site of ongoing struggle concerning which the conclusion is far from resolved. What is certain is that the school curriculum is likely to remain a focus for projecting and reflecting both change and continuity in the broader struggle for transition, even though the long-term outcomes remain 'tentative' and 'uncertain'.

\section{Notes}

1. This study is part of a broader comparative research programme which examines curriculum policy and social transition in Namibia, Zimbabwe and South Africa. The Namibian component of the study is based on visits to Windhoek, Tsumkwe, Rundu and Katima Mulilo during 1993. The research reported here builds on at least 25 interviews with senior Ministry officials in the Windhoek office of the Ministry of Education and Culture, and several interviews with regional education officials (including inspectors, school principals and teachers) in the northern parts of the country. In addition to interviews, the study is based on an extensive review of official documentation (broad educational policy framework documents, curriculum policy documents such as school syllabuses, classroom-based schemes of work, old and new textbooks, and examination materials) and selected classroom observations in rural schools.

2. While the British Dominion of South Africa occupied Namibia in 1915 after the outbreak of the First World War in 1914, South Africa was only 'officially' granted a League of Nations mandate to rule Namibia in 1920.

3. For a detailed critique of the theoretical contribution of Carnoy and Samoff (1990), see Jansen (1919a) as well as the rebuttal by Carnoy and Samoff (1991: 75-80) in the same journal issue.

4. The construct 'late colonial states' is used here to refer to both a period and a process. The period of concern is the late 1980 s by which time most African states had already gained independence from European colonial powers. The process refers to policy development in a national context in the late 1980x under conditions 
which militated against radicalism in national policy in an era of new global politics which claimed 'the triumph of capitalism' and the 'the defeat of socialism'. By contrast, among post-colonial states emerging during the 1960s and 1970s, national policy development was cast in terms of anti-capitalist orientations and a collectivist spirit supported materially and ideologically by the socialist states in the East.

5. For a detailed if self-congratulatory report on the immediate pre-independence negotiations see Chester Crocker's (1992) High Noon in Southern Africa.

6. This literature is well established in the USA (Apple 1979, McCarthy 1990) and Europe (Whitty and Young 1976, Weiler 1990) but has recently also emerged in the curriculum literature of southern Africa (Jansen 1990, Nkomo 1991, Taylor 1993). In reference to this critical literature, a recent review concluded that: 'the effort to understand curriculum as a political text must be regarded as one of the great achievements of the curriculum field since the 1970s' (Pinar and Bowers 1992: 185).

7. A challenge to future scholarship would be to examine more closely the ways in which professional knowledge and scientific expertise were mobilized by the South African state not only to justify official policy within its own borders but to extend this legitimizing knowledge/expertise to its shaping of Namibian policy. In this respect, the Van Zyl Report on education, the Odendaal Report on homelands and ethnic government and the Wiehahn study on labour legislation represent starting points for examining the transfer of knowledge/power from South Africa to Namibia.

8. The so-called Etosha Conference (12-19 April 1991) was an important event in that it signalled directions for educational reform to be pursued by the new government. Both the President and the Minister of Education and Culture raised curriculum reform ('the content of curriculum' in the words of the President or 'What to teach' in the words of the Minister) to the top of the education reconstruction agenda. See papers C.W. Snyder (ed.)(1991) Consultation on Change: Proceedings of the Etosha Conference. First National Conference on Basic Education Reform (Tallahassee: Florida State University, Learning Systems Institute). However, the significance of curriculum was already clear at an important 1982 SWAPO Seminar on Education in Lusaka where 'curriculum development' was identified as one of 
three priority areas for reconstruction; teacher training and research on the education system were the other priorities (Ellis 1984: 61).

9. These consultants' reports include the report on reform priorities by John Turner, language policy by Thelma Henderson and in-service teacher training by a UNDP/UNESCO/UNICEF team.

10. See, for example, the Basic Education in Namibia: Sector Review Report, USAID December 1990.

11. While I am isolating the 'curriculum bureaucracy' for the purpose of this paper, the process of educational decision making is of course not so discrete organizationally but is in fact a complex interplay across all the administrative units responsible for developing and implementing educational policy.

12. Among others, see the USAID Sector Study (1990); the (draft) USAID/Creative Associates International Second Annual Review of Basic Education (1993); and the Namibia/South Africa Policy Dialogue Reports, Examinations Policy Section (1993). 


\section{References}

APPLE, M. (1979) Ideology and Curriculum (New York: Routledge).

APPLE, M (1993) Official Knowledge (New York: Routledge).

BethelL, G. (1990) Evaluation of Examination Needs of Primary and Secondary Schools (Windhoek: University of Cambridge Local Examinations Syndicate for the Ministry of Education and Culture).

Carnoy, M and SamofF, J., (1990) Education and Social Transition in the Third World (Princeton: Princeton University Press)

CARNOY, M. AND SAMOff, J., (1991) Education and Socialism in the Third World: a response. Canadian and International Education, 20(2): 75-80.

CROCKER, C (1992) High Noon in Southern Africa: Making Peace in a Rough Neighbourhood (New York: W.W. NORTON).

DAUn, H. (1992) Neo-liberalism, Structuralism and Primary Education in Mozambique, Swedish International Development Agency (SIDA): Education division Documents, No.58 (Stockholm: SIDA).

Directorate of Language Research and Development (1992) Preliminary Report on a National Survey of English Language Teaching in Primary Schools (Windhoek: Ministry of Education and Culture, Namibia).

DU PISANI, A. (1991) Rumours of rain: Namibia's post-independence experience. Southern African Issues, 3 (February).

Du ToIT, H. de V. (1990) The USSR and conflict in Southern Africa: Angola and Namibia. In J. Valenta and F. CIBULKA (eds) Gobarchev's New Thinking and Third World Conflicts (New Burunswick: Transaction), 171-191. 
Duncan, R.W. and EKEDAHL, C. McG. (1990) Moscow and the Third World under Gorbachev (Boulder: Westview).

ELLIS, J. (1984) Education, Repression and Liberation: Namibia (London: Catholic Institute for International Relations and the World University Service).

FAGEN, R.R. (1986) The politics of transition. In R.R. Fagen, C.D. Deere and J.L. Coraggio (eds) Transition and Development: Problem of Third World Socialism (New York: Monthly Review), 249-263.

HARLECH-JONes, B. (1992) Reviewing education in an independent Namibia. Namibia Review, (1(7): 1-6

JANSEN, J. (1990) Curriculum policy as compensatory legitimation? A view from the periphery. Oxford Review of Education, 16(1): 29-38.

JANSEN, J. (1991a) Education and socialism in the Third World: in search of explanations. Canadian and International Education, 20(2): 71-74).

JANSEN, J. (1991b) The state and curriculum in the transition to socialism: the Zimbabwean experience. Comparative Education Review, 35(1): 76-91.

JANSEN, J. (1993) Post-apartheid education: is Zimbabwe a model? In N. Taylor (ed.) Inventing Knowledge (Cape Town: Maskew Miller/Longman).

LIU, C. (1980) Colonial education and African resistance in Namibia. In A.T. Mugomba and M. Nyaggah (eds) Independence Without Freedom: The Political Economy of Colonial Education in Southern Africa (Santa Barbara: ABC-Clio), 152-171.

McCARTHY, C. (1990) Race and Curriculum (London: Falmer).

MCFAUL, M (1990) The demise of the world revolutionary order: Soviet-Angolan relations under Gorbachev. Journal of Southern African Studies, 16(1): 165-189. 
MEYNS, P. (1991) The new world order and Southern Africa in the 1990s. In A. van Nieuwkerk and G. van Staden (eds) Southern Africa at the Crossroads. (Johannesburg: South African Institute of International Affairs), 56-79

MINISTRY of Education and Culture (1992a) Annual Report for the Year ending 31 December 1992. Presented to the National Assembly of Namibia, Windhoek.

MINISTRY of Education and Culture (1992b) Toward Education for all: A Development Brief for Education, Culture and Training (Windhoek: Ministry of Education and Culture).

NAMIBIA Donors Conference (1990) Namibia: Challenging the Future (New York: Namibia Donors Conference).

NAMIBIA Support Committee (1988) Namibia 1884 - 1984: Readings on Namibia's History and Society, ed. B. Wood (London: Namibia Support Committee, and Lusaka: United National Institute or Namibia).

Nkomo, M.O. (1991) Pedagogy of Domination (Trenton: Africa World Press).

O'DonnelL, G.A. and SCHMITTER, P. (1990) Transitions from Authoritarian Rule: Tentative Conclusions about Uncertain Democracies (Baltimore: Johns Hopkins University Press).

PINAR, W. and BoWERS, C.A. (1992) Politics of curriculum: origins, controversies, and significance of cultural perspectives. In G. Grant (ed.) Review of Research in Education 18 (Washington, DC: American Educational Research Association), 163-190.

Pitswane, J. (1992) Namibia: challenges of the first decade. In L. Benjamin and C. Gregory (eds) Southern Africa at the Crossroads: Prospects for Stability and Development in the 1990s (Rivonia: Justified), 105-123.

Policy Dialogue Reports (1993) Reports from the Namibia-South Africa Policy Dialogue Workshop, June/July 1993. Prepared fro the Eskom/Midrand Report-Back Conference (Braamfontein: Advancing Basic Education and Literacy [ABEL] Project). 
SALIA-Bao, K. (1991) The Namibian Education system under the Colonialists (Randsburg: Hodder and Stoughton).

SAUL, J (1990) Socialist Ideology and Development in Africa (Trenton: Africa world Press).

SIMON, D. (1991) Independent Namibia one year on. Conflict Studies, 239: 1-26.

SpARKS, D.L. and Green, D. (1992) Namibia: The Nation After Independence (Boulder: Westview).

TAYLOR, N. (ed.) (1993) Inventing Knowledge (Cape Town: Maskew Miller/Longman).

USAID (1990) Basic Education in Namibia, Sector Review Report (Windhoek, Namibia: USAID).

WEILER, H. (1990) Curriculum reform and the legitimation of educational objectives: the case of the Federal Republic of Germany. Oxford Review of Education, 16(1): 15-28.

WHITTY, G and Young, M.F.D. (1976) (eds) Explorations in the Politics of School Knowledge (Driffield: Studies in Education).

Wood, B., (1993) Peace without losers? South Africa and Namibia's independence. In N. Thede and P. Beaudet (eds) A Post-Apartheid Southern Africa? (London: Macmillan), 5376.

WORLD BANK (1992) Namibia: Poverty Alleviation with Sustainable Growth (Washington, DC: World Bank). 